\title{
THE “CARA VALLE” ABBEY AND ITS REFECTORY
}

\author{
G. Guarisco ${ }^{1}$, D. Oreni ${ }^{1}$ \\ ${ }^{1}$ Politecnico di Milano, via Ponzio 31, Milan, Italy \\ (gabriella.guarisco; daniela.oreni)@polimi.it
}

KEY WORDS: conservation, historical techniques, degradation, 3d survey, water regulation system

\section{ABSTRACT:}

The Refectory of Chiaravalle abbey, still in use today, is a masonry building (with bricks that are not common in size), vaulted and characterized by complex stratifications that required careful cognitive analysis of the documentary sources, structural and physical analysis to be understood. To this aim, an accurate 3D laser scanner and photogrammetric survey was carried out during last years in order to obtain geometric information on the building and its complex elements, in scale 1:50. Those data were also fundamental to support the mapping of the different construction phases, the transformations and the dated additions, to be compared to the archive, iconographic and photographic documents. A canal derived from the Vettabbia, which served to move the blades of the mill (now reactivated), flows right under the Refectory causing the usual phenomena of degradation. Saint Bernard had chosen this place because it was rich both in water, and therefore highly productive, and in clayey soil, which allowed the construction of the buildings of the abbey. However, today the strongly compromised irrigation and water regulation system (especially after the construction, in 2003, of the large purifier in Milano Nosedo) represents the main factor of degradation for all the buildings of the monastic complex, in particular for the Refectory.

The purpose of this paper is to present the main results of the studies and surveys conducted on the Chiaravalle abbey in the last ten years, focusing in particular on the Refectory.

\section{INTRODUCTION}

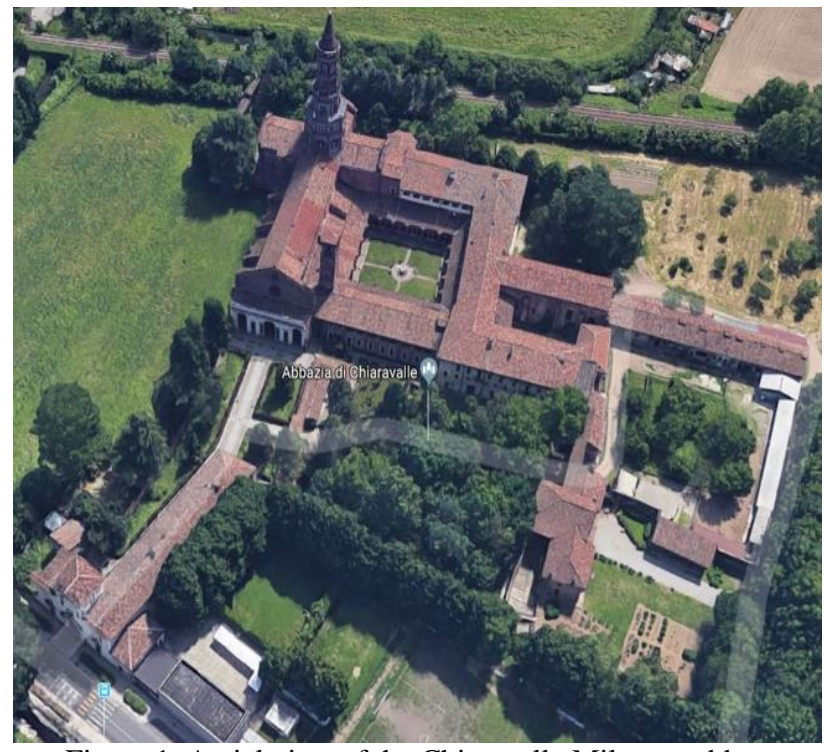

Figure 1. Aerial view of the Chiaravalle Milanese abbey (Google@ 2019)

The Cistercian abbey of Chiaravalle Milanese is located in the park of the Vettabbia and now it is included in that extraordinary enclave bounded by the connection of the eastern and western Milan ring roads. The abbey remains one of the most significant complexes among those built by the Cistercians and it is a place dear to the Milanese citizens. In addition to the church, dedicated to Santa Maria "di Rovegnano" and consecrated in 1221, the abbey was founded in 1135 by San Bernardo da Clairvaux and preserves all the buildings used for various purposes: the guesthouse, the mill, the dormitories, etc., and the Refectory (dated to the thirteenth century) ${ }^{1}$ ). In the course of its millennial existence, many changes occurred to the different buildings, but the church and the Refectory remain among the oldest and therefore one of the most complex to understand, especially because of the past restoration activities.

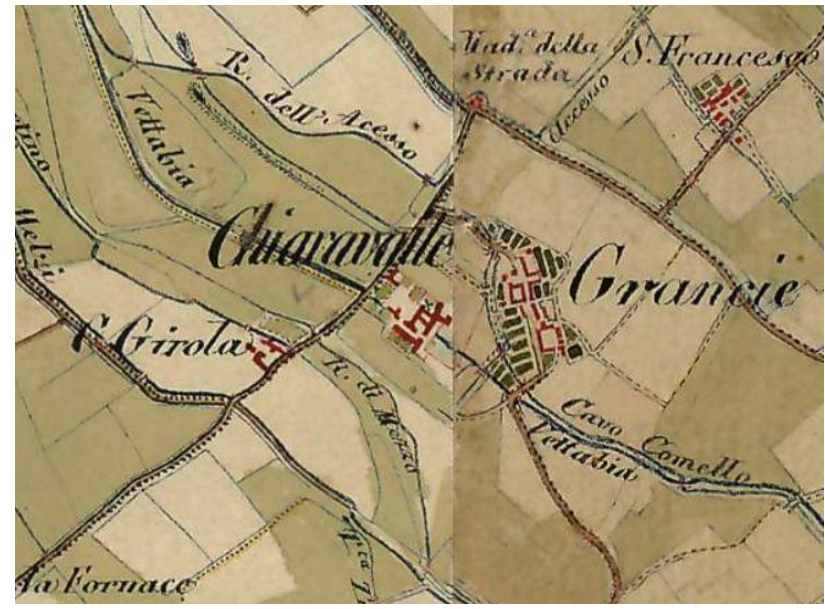

Figure 2. Second military survey of the Habsburg Empire, Lombardy, Venice, Parma, Modena (1818-1829).

(Österreichisches Staatsarchiv)

1.1 Notes on the construction and transformation of the Refectory

After the construction of the church of Santa Maria, on the southern side of the small cloister were built the kitchen, with the adjoining services and the Refectory. In 1442, the Refectory, the dormitory, the cloister, the mill and the rural buildings remained to the Cistercians. The "commendatario" who, from 1464, was Ascanio Sforza, administered all the other buildings: the guesthouse, the tower at the entrance and all the buildings up to the Vettabbia. In May 1798 the Cistercian congregation was suppressed, the monastery dismembered and the Refectory 
divided into two rooms; the ancient cells of the monks were destructed and the monastery was in part transformed into unhealthy civil houses. In 1861, due to the construction of the Milan-Genoa railway line, the large Bramante cloister was demolished and only one side of the small cloister remained. The church and the Refectory remain "intact".

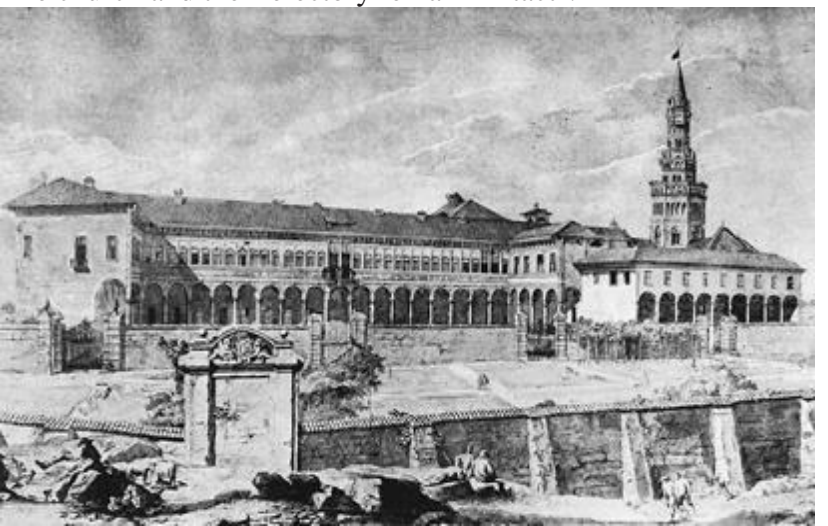

Figure 3. D. Aspar, "General view of the abbey of Chiaravalle, now demolished" (Beltrami, 1918)

In 1952, the Cistercians returned to Chiaravalle because of the agreement signed with the Municipality of Milan, which provided for the concession on condition that all the buildings were restored. A long series of restorations began, conducted by Ferdinando Reggiori $\left({ }^{2}\right.$ ) and subsequently (after 1976) by Alfonso Lamperti, who carried out the major restorations of the Refectory.

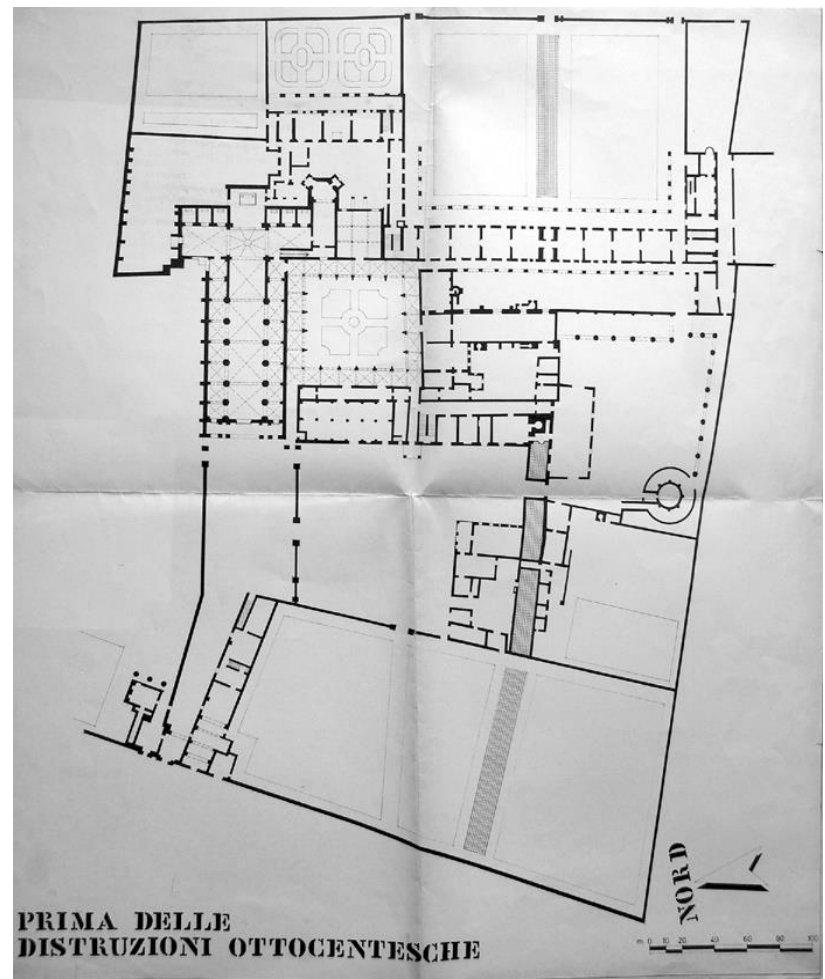

Figure 4. The abbey complex "Before the destruction of the nineteenth century" (AACMi)

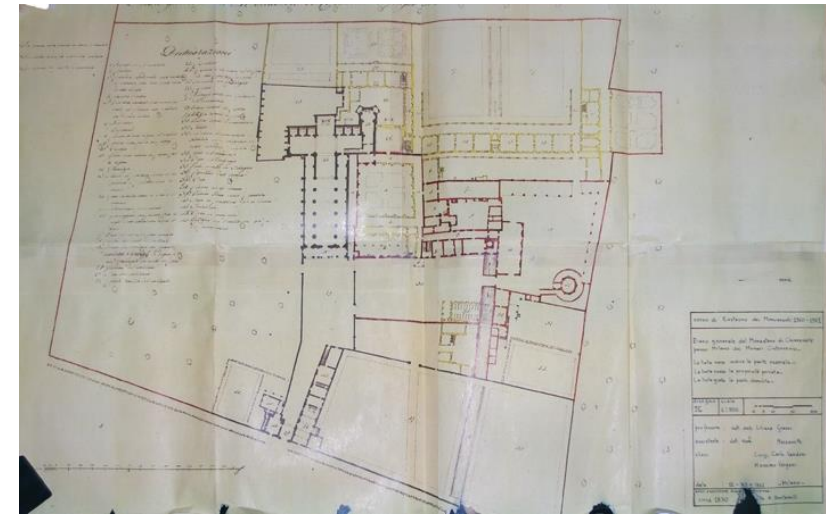

Figure 5. L.C. Vandoni and M. Vergani, "General plan of the Monastery of Chiaravalle near Milan of the Cistercian Monks" (course of Restauro dei Monumenti, Prof. L. Grassi with P. Mezzanotte). Based on the 1830 drawing, the revenue part is represent in black; the private property is in red; the demolished part in yellow (AACMi)

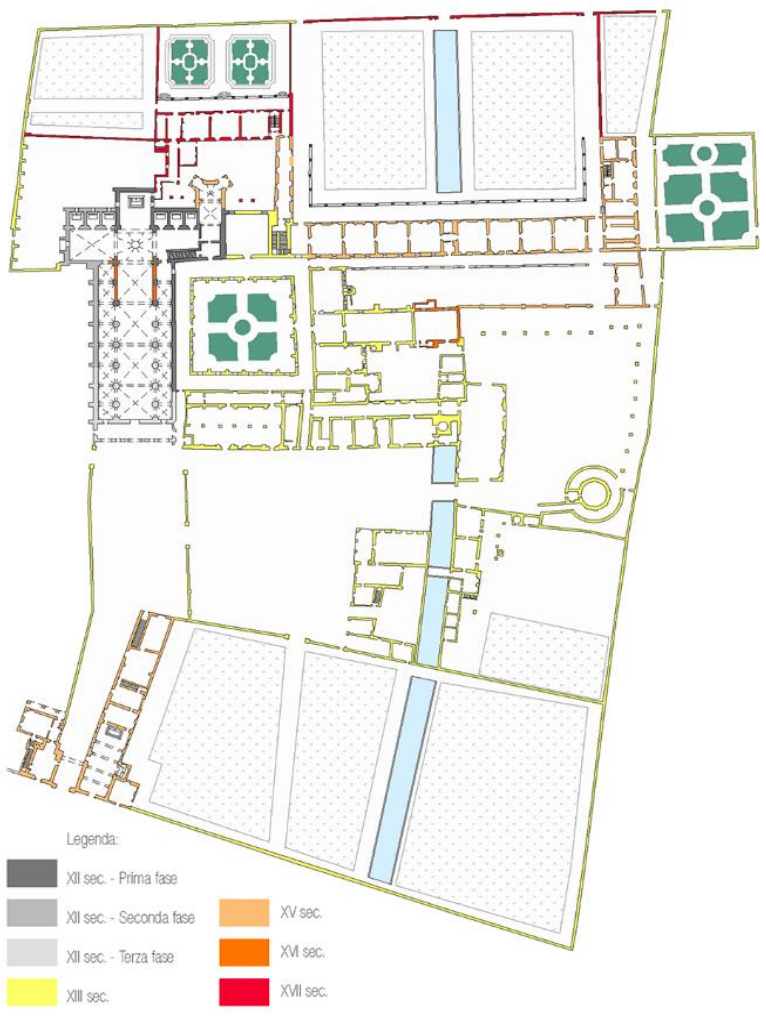

Figure 6 . The construction phases of the abbey complex from 1135 to the eighteenth century, with the extension of the Refectory dated to the sixteenth century (Master thesis of V. Olearo, A. Bellinetti, L'Abbazia di Chiaravalle Milanese e la sua foresteria. Conoscere e valorizzare l'esistente, conservare la fabbrica e progettare nuovi spazi di fruizione, Prof. G. Guarisco and Prof. N. Lombardini, with architect G. Clerici, Politecnico di Milano, Scuola di Architettura Urbanistica Ingegneria delle costruzioni, corso di laurea magistrale in Progettazione architettonica, a.y. 2016-2017) 


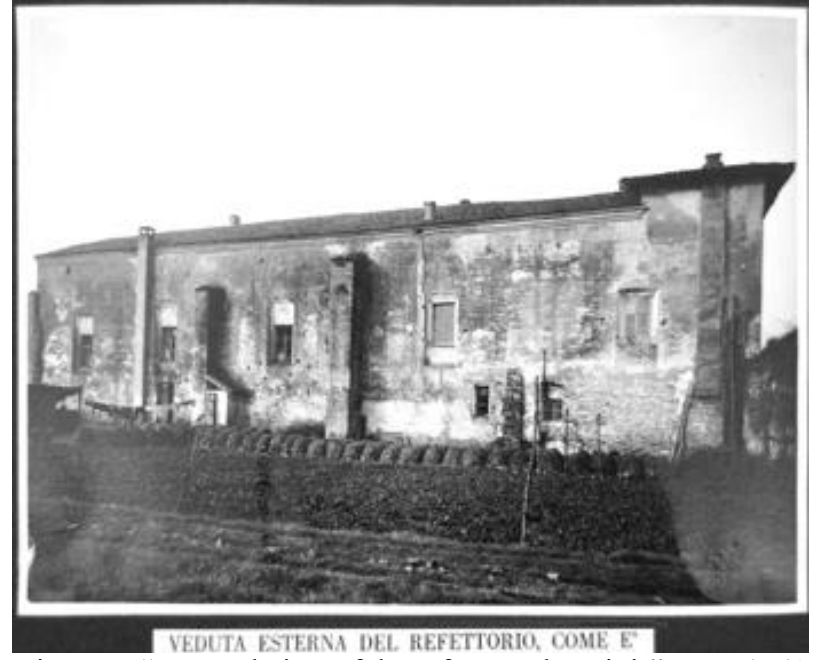

Figure 7. "External view of the refectory, how it is" (Reggiori?, 1952) (SABAPMi, AV, 17)

\section{KNOWLEDGE OF THE REFECTORY}

The Refectory is one of the oldest buildings in the abbey complex. This peculiarity has led to the widening of the research to disciplinary areas close to restoration (since 2015). Initially archival and bibliographic research was carried out, as well as in situ research on the building, using traditional instruments.

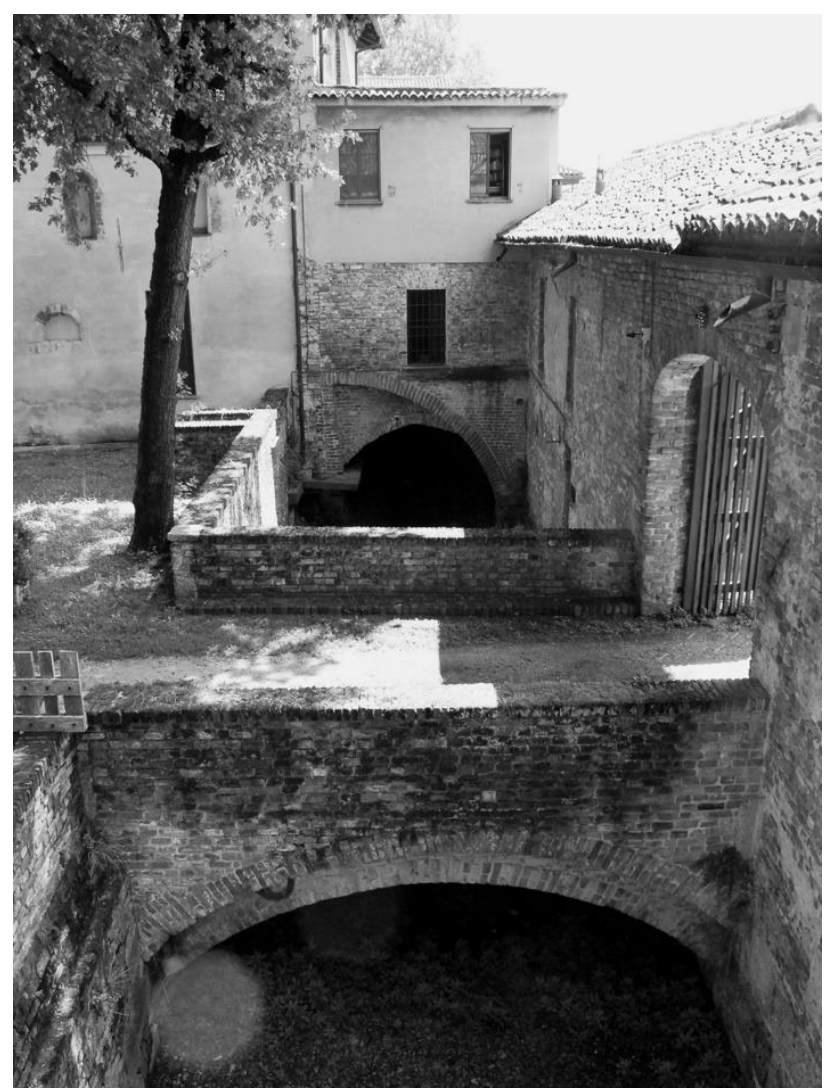

Fig. 8. View, from the mill, of the canal that runs south of the cloister, under the arm of the converts and the Refectory

(Schiavi, 2016)

Afterwards at least two essential skills were used to understand the geometrical "anomalies" of the building. On the one hand, the digital survey techniques, to obtain accurate $3 \mathrm{~d}$ data and to highlight and solve some of the questions about the shape of the building and its elements (out of plumb, construction discontinuities, etc.). On the other hand, the historians of medieval architecture who have provided further information on the state of consistency of the building and innovative methods of research.

As the bibliographic and archival documentation demonstrate, the Refectory has been transformed several times and the possibility to carry out an accurate survey represented the opportunity to compare the two levels of knowledge. For example, archive documents show that the large rectangular windows on both longitudinal walls were built during the 17th century. This intervention caused the closing of the medieval single-lancet windows, partially re-opened during the subsequent restoration activities.

A further investigation concerned building materials: the bricks of the Refectory walls have unusual dimensions (fig. 9), as confirmed by the most recent medievalist historiography (Schiavi, 2019). Considering what was previously sanctioned on the construction rule "Ad Quadratum" (Aubert, 1943) (Romanini, 1975) $\left(^{3}\right)$, in recent years, the research has focused on the Cistercian construction systems of the 12th century, so different from the "Lombard architecture" (so dear to 19th century researchers). In fact, and especially in Italy, where the rule of construction was dictated by St. Bernard, the rooms were distributed around the claustrum, usually built on a single level using stone and/or terracotta as building materials. The distribution of the rooms followed the same modular square used to build the church, both in plan and in elevation. Generally, the rooms dedicated to the monastic life have a square or rectangular shape, internally divided according to a scan of pillars and vaults. That scan is the result of a proportional subdivision of the module.

The only space in the private cloister that have a direct relationship with the church in front of it, both in elevation and in the modular plan, is the Refectory. That building have a single nave basilica system. The cloister has ophitic columns, typical elements of Cistercian architecture, but they were almost certainly relocated during the past restoration campaigns.

The oldest part of the Refectory walls is built with irregular and not standardized size bricks, and lime mortar joints.

The prevalent form of deterioration in the building is the rising humidity present in all the walls. Referring to other investigations aimed at finding out the degree of absorption of moisture in the walls, it is inevitable to point out that the Refectory (figs. 7-8), or at least its extension, is built above the canal of deviation of the Vettabbia that gave water to the mill. Today that water system, which flow was determined by a very delicate and wise system of sluices, has been partially upset, but recently (2017) the mill blades have been restored and the water has returned to flow in the canal during some events.

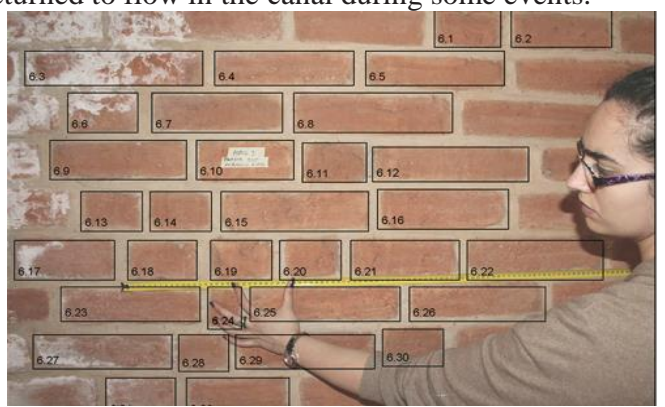

Figure 9. Identification of the bricks (Laboratorio di Restauro I, G. Guarisco and N. Lombardini, laurea Magistrale in Progettazione architettonica, Politecnico di Milano Scuola di Architettura Urbanistica Ingegneria delle Costruzioni, a.y. 2015-2016) 

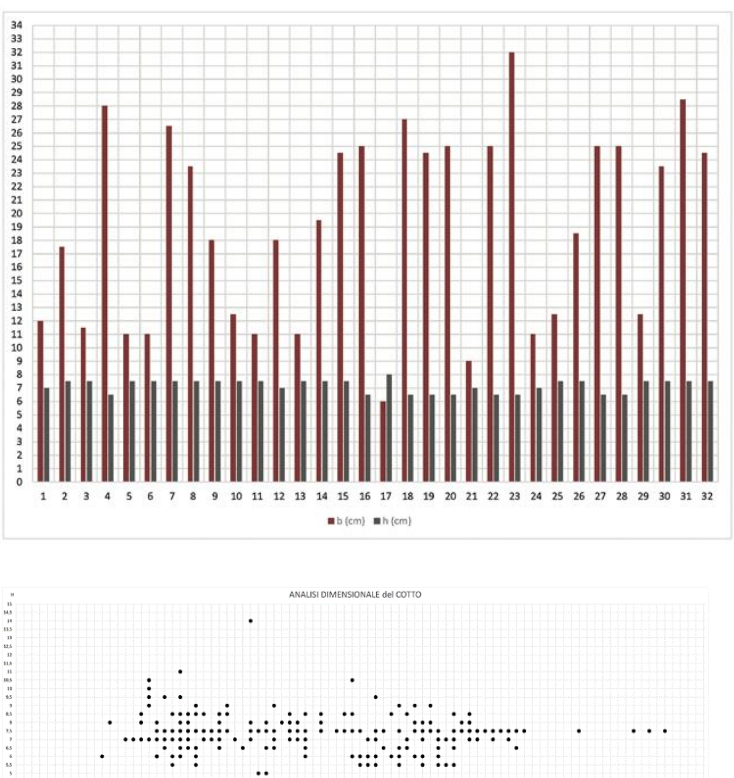

Figure 10. From above: graph of the bricks sizes and dimensional analysis of the terracotta elements (Laboratorio di Restauro I, G. Guarisco and N. Lombardini, a.y. 2015-2016)

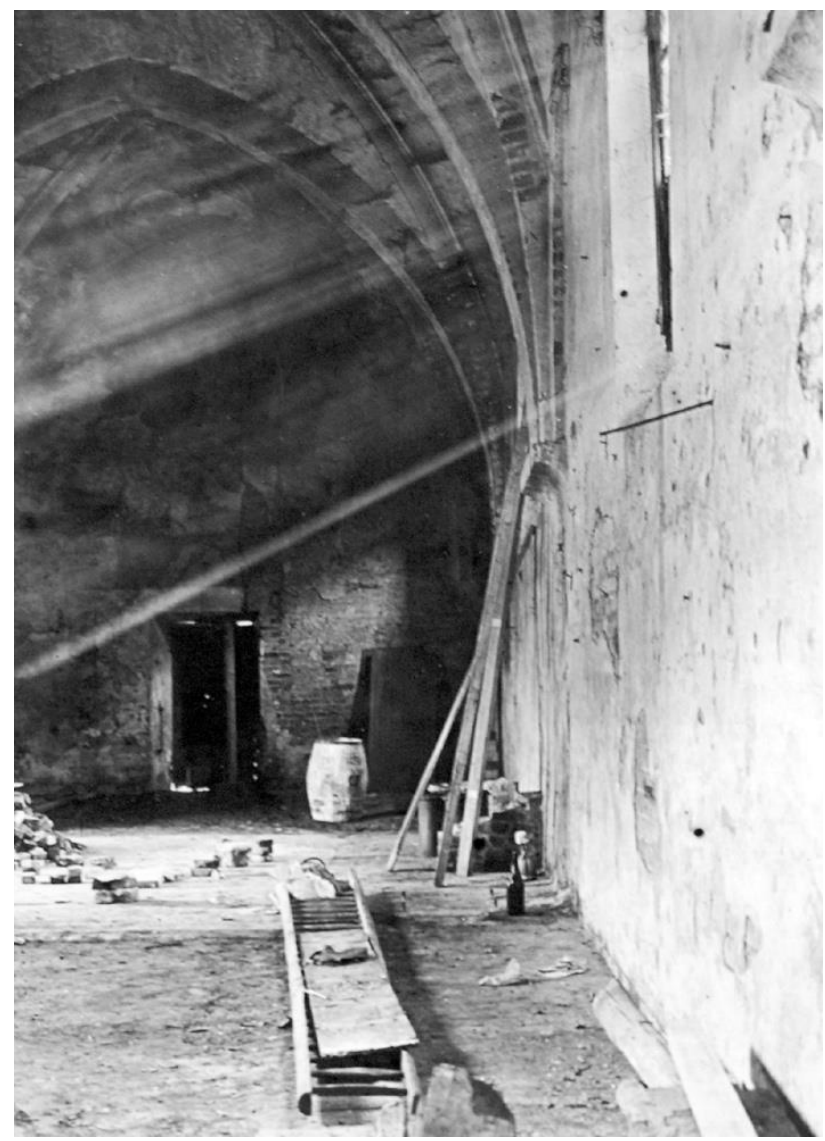

Figure 11. The interior of the Refectory in a picture that documents the state of consistency before the restoration of Ferdinando Reggiori. On the back wall there is still the door then closed and the walls are plastered. Therefore, the photo dates back to the beginning of the works carried out by Reggiori (fig. 12) (AACMi)

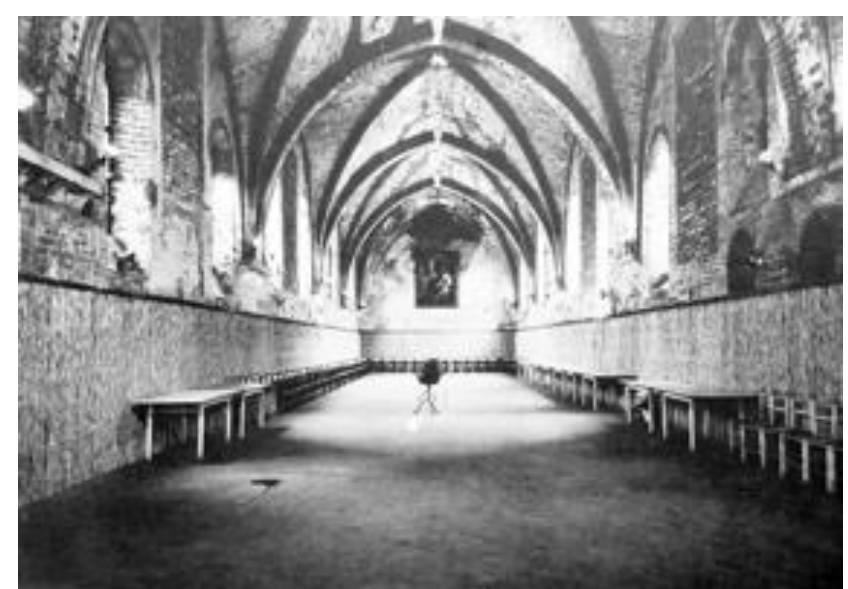

Figure 12. View of the interior of the Refectory after the restoration of Reggiori and before the subsequent restoration by Lamperti (AACMi)

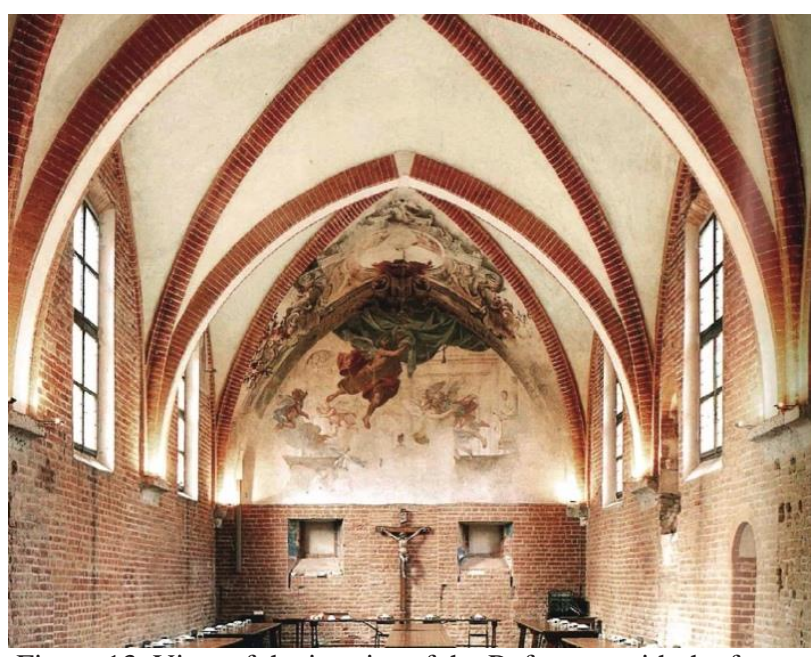

Figure 13. View of the interior of the Refectory with the fresco on the back wall and the closed door where the Crucifix is placed

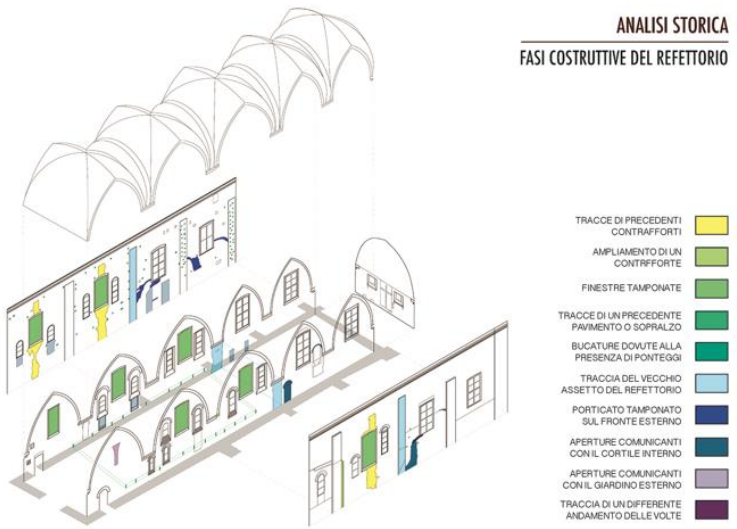

Figure 14. Axonometric representation of the historical evolution of the Refectory (Laboratorio di Restauro I, G. Guarisco and N. Lombardini, with architects G. Clerici and D. Mirandola, laurea Magistrale in Progettazione architettonica, Politecnico di Milano Scuola di Architettura Urbanistica Ingegneria delle Costruzioni, a.y. 2015-2016) 


\section{THE SURVEY AS AN INSTRUMENT OF COGNITIVE INVESTIGATION OF THE BUILDING $\left({ }^{4}\right)$}

\subsection{The surveying activities of the cloister and the Refectory}

The survey of the cloister and the Refectory $\left({ }^{5}\right)$ are part of this extensive project of knowledge and geometric investigation of the abbey of Chiaravalle, carried out in order to update and implement the existing surveys on the different buildings. The restitution, analysis and interpretation of the data surveying have made it possible to investigate the aspects linked to the geometry of the buildings and their construction elements, as they have come to us today after centuries of transformations and restorations.

The instrumental survey of the Refectory was carried out in $2017\left({ }^{6}\right)$, both internally and externally, towards the buildings to the south (dormitories and stables for animals). Several integrated survey techniques were used: laser scanning $\left({ }^{7}\right)$, photogrammetry, but also direct surveying, at a scale of representation between 1:50 (plants and fronts) and 1:5 (construction details).

The three-dimensional point cloud made it possible to accurately investigate the geometry of the Refectory and its spatial relations with the adjacent buildings and cloister. In particular, after the processing of laser scanner data it was possible to carry out a multiple series of horizontal and vertical sections for the drawing of plants at different heights, sections and elevations. These data have also made possible a series of fundamental measurements for the interpretation of the different parts of the building, to be related to the history of their transformations over the centuries.

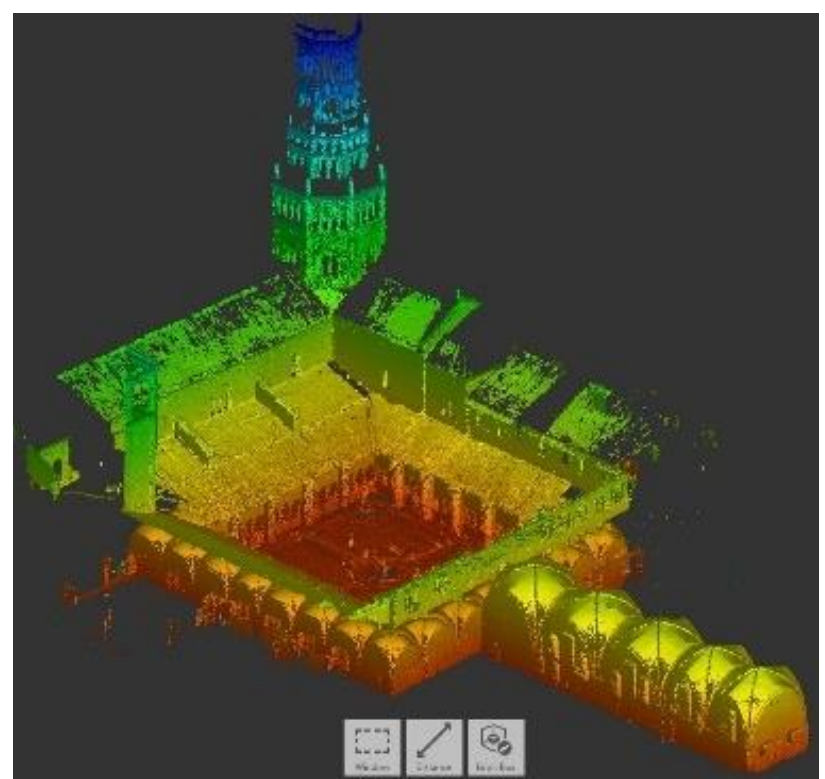

Figure 15. The 3D laser scanner cloud of the Refectory and the cloister close to the church and the "Ciribiciaccola"

The control points used to obtain the rectified images and orthophotos of the internal and external $\left({ }^{8}\right)$ fronts were derived from laser scanner points cloud, with the final aim of representing the shape, the geometry and the semantic content of this architecture. The rectified images were obtained following a project of acquisition of the images in scale of restitution 1:50. This scale is fundamental for the subsequent phases of thematic mapping: the analysis of the materials, the pathologies of degradation (fig. 19) and the volumetric stratigraphy.

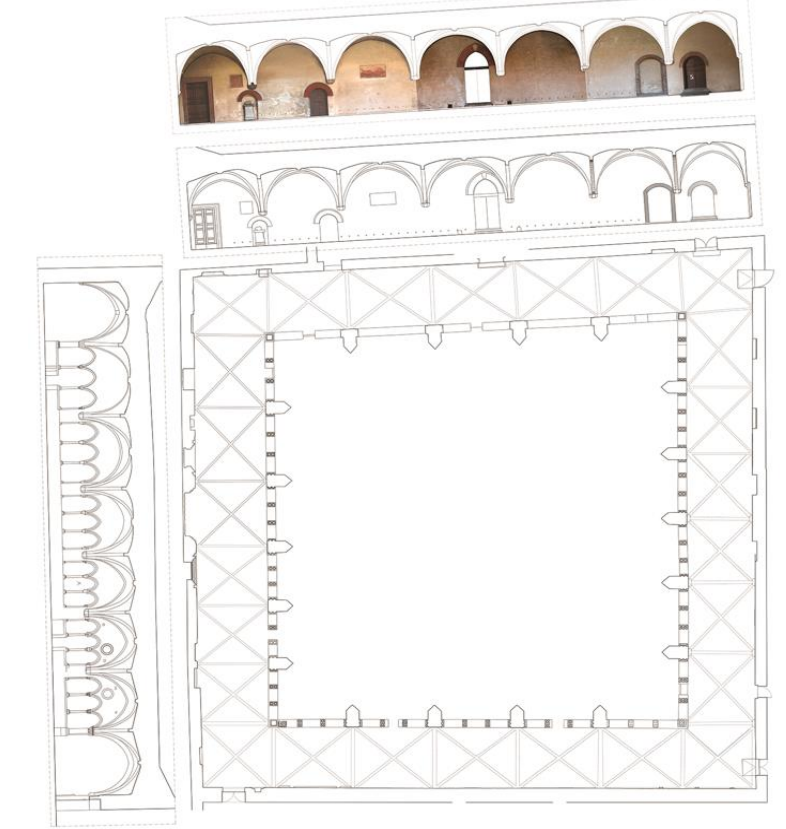

Figure 16. Plan of the cloister obtained from laser scanner data with internal elevation and rectified image of the front towards the Refectory. The central door in the rectified image is the one that gives access to the Refectory from the cloister (Laboratorio di restauro, G. Guarisco and D. Oreni, Politecnico di Milano, Scuola di Architettura Urbanistica Ingegneria delle Costruzioni, Corso di laurea in Architettura, Ambiente costruito, Interni, a.y. 2017-2018)

The digitalization of the internal and external fronts was carried out using integrated data, the point clouds, the rectified images and the measures of the details obtained with direct measurements, using also sketches, which are critical tools indispensable for a preliminary analysis of the building, its parts and its proportions.
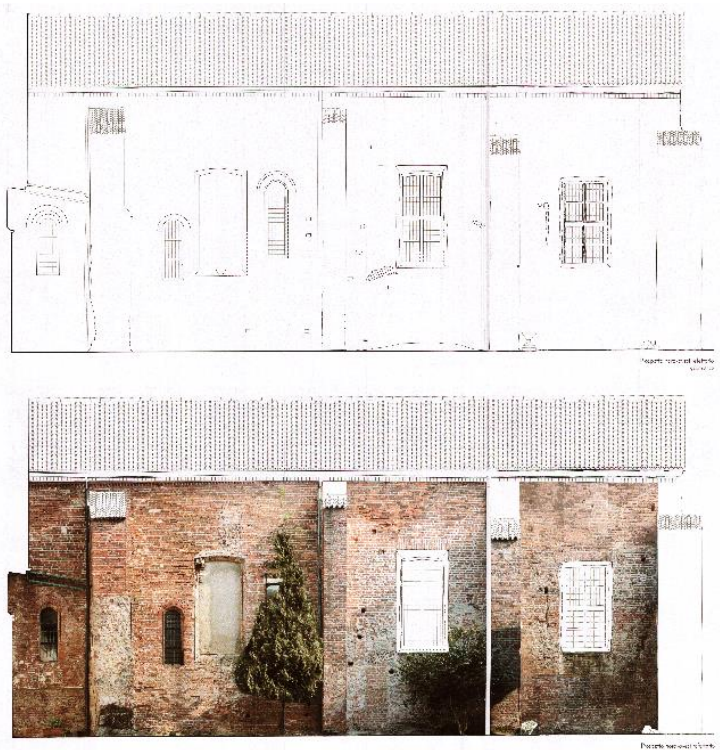

Figure 17. Front and rectified image of the west side of the Refectory, in scale 1:50 (Laboratorio di Restauro, G. Guarisco and D. Oreni, a.y. 2016-2017) 


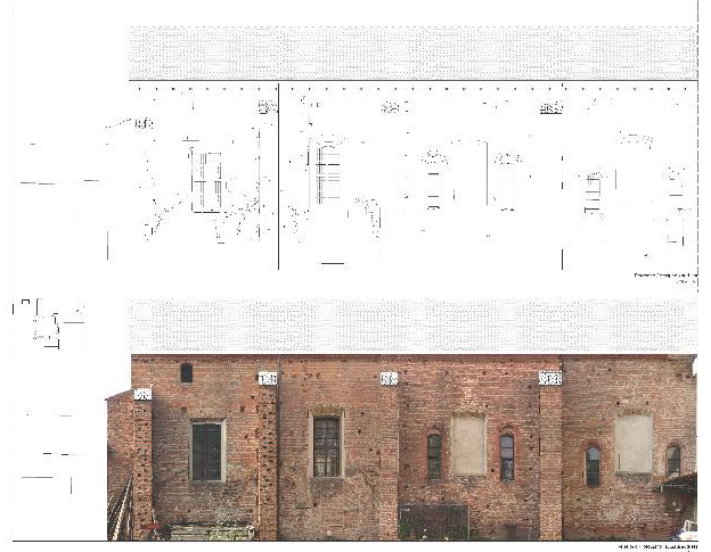

Figure 18. Front and rectified image of the est side of the Refectory, in scale 1:50 (Laboratorio di Restauro, G. Guarisco and D. Oreni, a.y. 2016-2017)
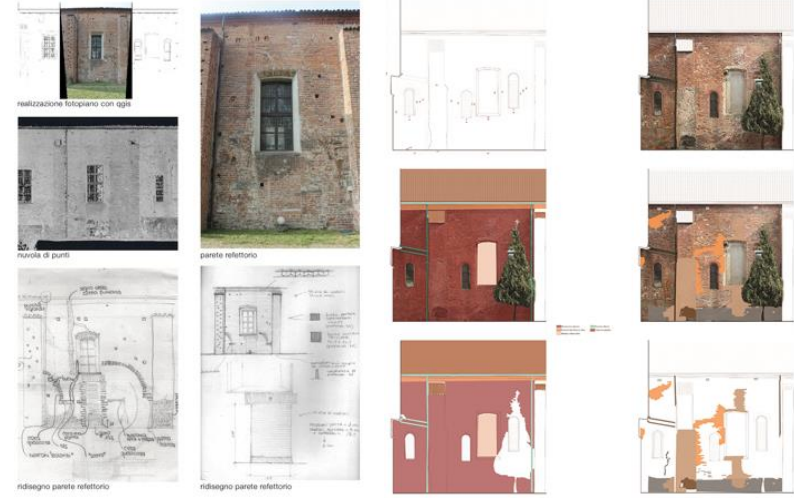

Figure 19. On the left, the process to obtain external rectified images of the Refectory using both direct measurements and laser scanner control points. On the right, the mapping process of materials and degradation pathologies of the west front of the Refectory (Laboratorio di Restauro, G. Guarisco and D. Oreni, a.y. 2016-2017)

\subsection{The geometry and the spaces of the Refectory}

The possibility of having an accurate three-dimensional survey of the Refectory has allowed to make a series of geometric and constructive observations on the shape of the building and its parts, on its relationship with the cloister and the other buildings. These observations, integrated with those of stratigraphic and material, made possible to compare the geometrical anomalies a irregularities surveyed with the results of the archival research and the history of past restoration activities. The geometries and materials, if correctly interrogated, are in fact able to give precious fragments of a construction history, which, in this case, is still partly to be written.

From the planimetric point of view, the Refectory has a single rectangular nave with five irregular spans, and has an internal dimension of about $38 \times 8$ meters. The five spans (fig. 20) have variable shapes and sizes: the first three (the ancient ones), entering to the north from the cloister, have a quadrangular plan and internal dimension of about $8 \times 8$ meters. On the other hand, the last two have a rectangular plan, with internal dimensions of about $6 \times 8$ meters. The thickness of the two longitudinal walls is $72-75 \mathrm{~cm}$ in the first three spans, while in the last two of 82$85 \mathrm{~cm}$. The northern wall that divides the Refectory from the cloister is $62-63 \mathrm{~cm}$ thick, while the southern wall is $88 \mathrm{~cm}$ thick.
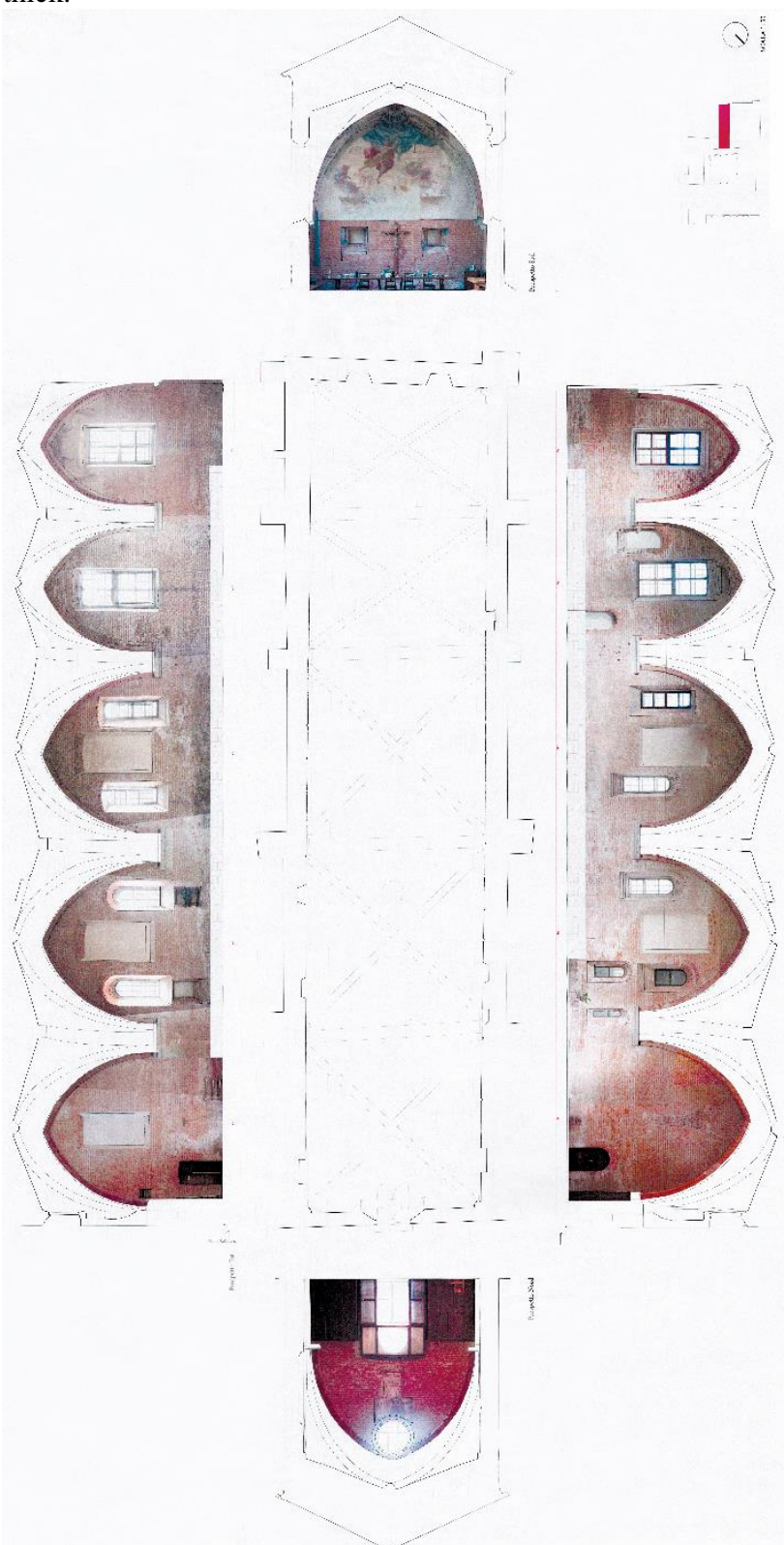

Figure 20. Plan, internal fronts and rectified images of the Refectory, scale of 1:50 (Laboratorio di Restauro, G. Guarisco and D. Oreni, a.y. 2016-2017)

This planimetric differences between the dimensions of the internal spans are also observable in the elevation, where the springing line and the hinge of the five ribbed cross vaults is the same (hinge height from the ground about $9.50 \mathrm{~m}$ ), but the volume of the various spans is different in size and spatiality.

The analysis of these dimensional differences between the first three and the second two spans allow recognizing two different construction phases of the building.

The five large deep cross vaults, set (about 3 metres from the floor) on pointed arches, give the room a great plasticity and sumptuousness, completed by the effect of the light that today enters through the large side windows, between the transverse arches. The vaults are in brick, plastered and have a very regular geometry; a large circular oculus, with a diameter of $95 \mathrm{~cm}$, is in the centre of the second cross vault. 
Regarding the current openings (omitting here the dimensional analysis of the walled up windows and doors, which can be easily measured starting from the recognition of the visible stratigraphic signs), it is once again possible to observe a difference between the first three spans and the last two, to the south. In the first three spans, the windows have different dimensions, shapes and layouts in plan and elevation. On the contrary, in the last two spans the position of the large rectangular windows and their dimensions are similar to each other (similar also to the walled up windows in the first three spans). This evidently also documents the planning choice that guided the restoration activities carried out by Lamperti architect, aimed at leaving partially legible the stratigraphic complexity of the walls (figs. 17-18-20). For this reason, the masonry surface of the walls remained visible and not plastered. The four external buttresses, both on the east and west side of the Refectory, have different dimensions and they are located approximately in correspondence with the springing line of the internal vaults. Evidently added later, the buttresses are not connected to the brick masonry and they were not built in the same constructive phase, as can be seen clearly by observing the stratigraphic signs on the walls.

What is interesting to analyse are the vertical sections of the perimeter walls, where there are significant out of plumb and geometrical irregularities. The out of plumb are more accentuated in correspondence with the points of greatest thrust of the internal vaults (springing line of the arches), where they were therefore inserted in the past the buttresses just mentioned. The out of plumb, characterized by the rotation of the walls outwards, have different values: in correspondence with the first and the third buttress from the north, the walls has an inclination of between 13 and $15 \mathrm{~cm}$ with respect to the vertical (height of the wall about $10 \mathrm{~m}$ ). On the other hand, there is no out of plumb in correspondence with the second buttress, between the second and third spans, which explains the small dimension of these reinforcement elements compared to the other four (up to $160 \times 170$ × $880 \mathrm{~cm}$ ).

The south-west corner buttress has an "L" shape; this element closes the Refectory to the south, whose walls, however, do not have geometric irregularities in the vertical direction. The same happens for the two buttresses that close the southeaster corner of the Refectory (fig. 22). All the buttresses at the corner of the Refectory, close to the rural buildings, are in exact correspondence with the south bank of the canal that flows under the last span of the building (figs. 21-22-23).

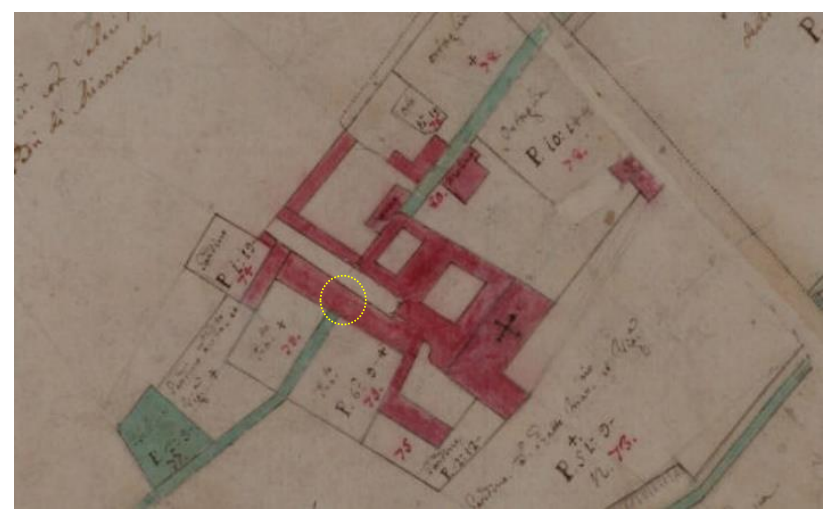

Figure 21. "Catasto Teresiano, mappe originali del primo rilievo", 1720-1723 (ASMi): in yellow the position of the canal under the last span of the Refectory

The presence of this canal is well documented not only in the archive drawings of the abbey but also in the historical cartography (fig. 22). The artificial vaulted canal runs at only 80 $\mathrm{cm}$ from the inner floor of the Refectory and it is 4 metres wide at this point. A round barrel vault covers the visible external part of the canal, but the vault changes its shape in correspondence with the east wall of the building, becoming a lowered barrel vault. The hinge of the external round barrel vault coincides exactly with the level of the internal floor of the Refectory (fig. 23).

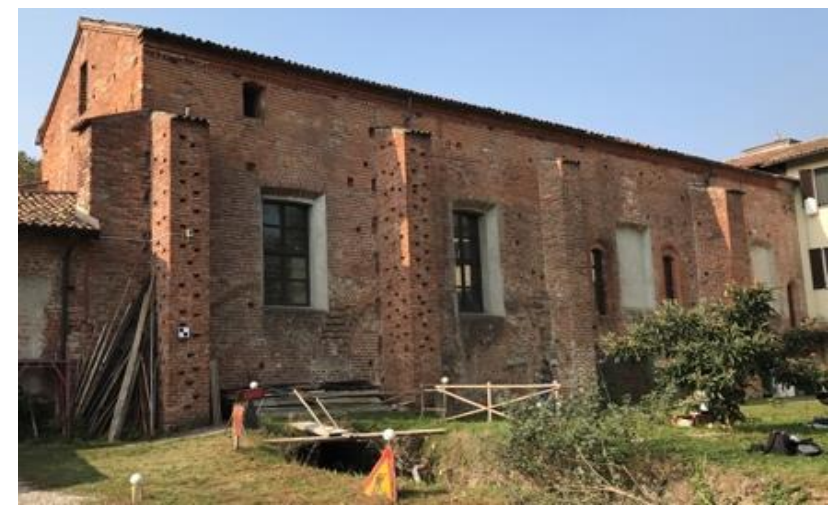

Figure 22. Photo of the eastern front of the Refectory with the canal in the foreground (photo October 2017)

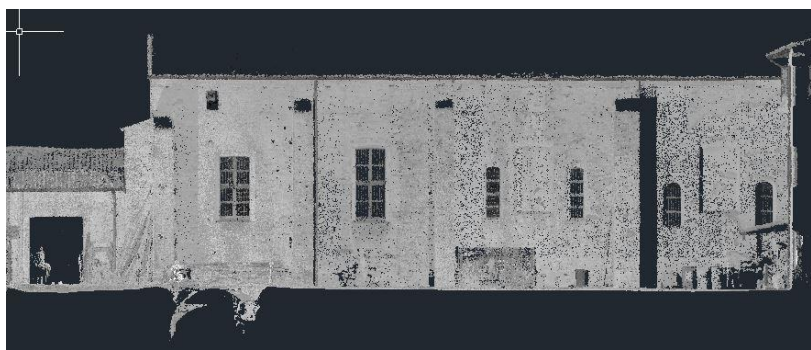

Figure 23. Point cloud of the eastern side of the Refectory with the outline of the canal placed under the last southern span

\section{CONCLUSION}

The cultural enhancement of historic buildings is impossible without the contribution of different skills, whose research must be crossed. In the prosecution of the research, it will be essential to compare all the registered data with the information derived by scholars in other fields (geologist, physico-chemist, etc.) researches. Because of a deep and wide knowledge of a historic building must be the only solid basis on which to plan a conservation and reuse project, respectful of the complexity of the existing, without incurring in irreparable damage that a careless approach would cause. History is always the teacher of life.

\section{ACKNOWLEDGEMENTS}

For their active collaboration, we would like to thank the Abbot, Padre Stefano Zanolini, and the Prior, Padre Michelangelo, who opened the archives and the buildings for the surveys.

\section{REFERENCES}

Caffi, M., 1842. Dell'abbazia di Chiaravalle in Lombardia. G. Gnocchi, Milano. 
Paravicini, T.V., 1889. L'abbazia di Chiaravalle Milanese. Vallardi, Milano.

Mella, E., Mella, F., 1912. Uno studio di Edoardo e Federico Mella sull'abbazia di Chiaravalle milanese con introduzione di Luca Beltrami. Tipografia U. Allegretti, Milano.

Beltrami, L., 1915. Opere d'arte disperse già appartenenti alla chiusura del coro all'Abbazia di Chiaravalle. Rassegna D’Arte, VII.

Beltrami, L., 1918. Veduta generale dell'Abbazia di Chiaravalle in un'iscrizione sconosciuta di Don Aspar. Bollettino dell'arte, V-VIII.

Aubert, M., 1943. L'architecture cistercienne en France. Les Éditions d'art et d'histoire, Paris, v. 2.

Bagnoli R., 1957. Chiaravalle milanese. La chiesa e il monastero. Maestri Stampa, Milano.

Bagnoli, R., 1955. Il Monastero di Chiaravalle. Milano: rivista mensile del Comune.

Fraccaro De Longhi, L., 1958. L'architettura delle chiese cistercensi italiane, Ceschina, Milano.

Reggiori, F., 1970. L'abbazia di Chiaravalle. Banca popolare di Milano, Milano.

Romanini, A.M., 1975. Le abbazie fondate da San Bernardo in Italia e l'architettura cistercense "primitiva". Studi su S. Bernardo di Chiaravalle nell'Ottavo centenario della canonizzazione, Editionies Cistercienses, Roma.

Viti, G., 1995. Architettura Cistercense, Fontenay e le abbazie in Italia dal 1120 al 1160. Casamari, Firenze.

Schütz, B., 2004. L'Europa dei monasteri, Architettura, arte e storia. Edizione italiana a cura di Roberto Cassanelli, Jaka Book, Milano.

Schiavi, L. C., 2016. Sul primo impianto della chiesa abbaziale di Chiaravalle Milanese. Arte Medievale, IV, VI.

Schiavi L. C., 2019. La cultura costruttiva nella Lombardia meridionale alla metà del XII secolo. La funzione cistercense, in print.
1 "Il refettorio è tutto antico e non ha subito alcuna trasformazione: vi è un 'immagine del Redentore nostro in croce, con la madre, il discepolo, e altre figure, se non in perfette condizioni comunque degno di nota, ai piedi del quale vi sono dei versi latini" (Fraccaro De Longhi, L., 1958, p. 81). From De Blanchi, B., (1556-1601), Notizzie Historiae Chronologiche e degli Interessi del venerando Monastero cistercense di Chiaravalle. Archivio abbazia Chiaravalle.

2 "Si vuole, innanzi tutto, reintegrare il chiostro piccolo, ricorrendo, per due lati, all'impiego di materiali giacenti in luogo; per il quarto lato, che verrà ad appoggiarsi al Refettorio e fabbricati vicini, si propone una soluzione più libera, a semplici arcate, essendo questo lato medesimo sviluppato anche in un piano superiore". From Reggiori, F., 30 gennaio 1955. Fondo AV, contenitore 13 (SABAPMi).

${ }^{3}$ M. Aubert (1943) and F. Dimier (1962) were among the first to present an innovative "type" plan of the Cistercian abbeys that carried out a rationalization of the Benedictine schemes (which descended from the Cluniac ones). The spaces were built according to a rigid modular scan of the territory. Later on, A.M. Romanini (1975) moved further the research on that square module, similar to "ad un blocco concluso in cuspide triangolare, moltiplicato per accostamento e sovrapposizione", which characterizes the plan of the Cistercian settlements of the twelfth century, wanted by St. Bernard.

${ }^{4}$ The opportunity to survey some of the abbey's buildings was provided by the Restoration Laboratories of the Master's degree course, starting from the academic year 2015-2016 (first annual and then half-yearly courses) up to the present year, with Prof. Nora Lombardini and Prof. Daniela Oreni.

${ }^{5}$ Together with these buildings, external surveys have also been carried out on the "Foresteria" (the results are currently being published).

${ }^{6}$ Course of "Tecniche avanzate di rilievo e rappresentazione", Prof. Daniela Oreni. The course is integrated in the "Laboratorio di restauro", Prof. Gabriella Guarisco. Politecnico di Milano, Facoltà di Architettura, laurea Magistrale in Architettura, Ambiente costruito, Interni, a.a. 20172018, 2018-2019.

${ }^{7}$ Laser scanner Faro Cam 2 Focus 3D, n. 10 scans, precision of about $\pm 2-3 \mathrm{~mm}$ and 220 million points inside the structure. Architect Daniela Oreni and engineer Luigi Barazzetti did the laser scanner survey.

${ }^{8}$ For the rectified images have been used different software, Perspective rectifier (analytical mode) and QGIS. Agisoft photoscan was used to obtain orthophotos.

$\begin{array}{ll}\text { AACMi } & \text { Archivio Abbazia Chiaravalle Milanese } \\ \text { ASMi } & \text { Archivio Stato Milano } \\ \text { SABAPMi } & \text { Soprintendenza Archeologia, Belle Arti e } \\ & \text { Paesaggio per la città metropolitana di Milano }\end{array}$

